\title{
ESTIMATION OF HUMAN STATURE FROM LENGTH OF ULNA IN INDIAN POPULATION
}

\section{Ashish Pandey ${ }^{1}$, Radhika P.M *2, Shailaja Shetty ${ }^{3}$.}

${ }^{1}$ Intern , Department of Anatomy, M S Ramaiah M edical College, Bangalore

*2 Assistant Professor, Department of Anatomy, M S Ramaiah M edical College, Bangalore.

${ }^{3}$ Professor \& HOD, Department of Anatomy, M S Ramaiah M edical College, Bangalore.

\section{ABSTRACT}

Introduction: Estimation of stature from measurement of various body parts is of particular interest to forensic scientist as it is considered as one of the basic parameters of the investigation process in unknown human remains in medico-legal cases. The aim of the study was to find out the relationship between personal stature and length of ulna.

Materials and M ethods: The present study was carried out on 300 (150 males and 150 females) students of M.S. Ramaiah M edical College of the age group of $18-28$ years. The parameters studied were height, length of right and left ulna. The observations were analyzed by Pearson's correlation to examine the relationship between length of ulna and height according to gender for right and left ulna separately.

Results: The mean and standard deviation of stature and length of both ulnas was derived. There was statistical difference between right and left ulna in both the gender. A positive correlation was found in both the gender. The correlation of stature with ulnar length was observed which was found to be statistically significant. A linear regression formula was established for right and left ulna.

Conclusion: The estimation of stature from the length of ulna will be of practical use in M edico-legal investigations and in anthropometry.

KEY WORDS: Stature estimation, ulna, Bone length, Regression equation, Forensic Anthropology.

Address for Correspondence: Dr. Radhika P.M , Assistant Professor, Department of Anatomy, M. S. Ramaiah M edical College, M SRIT Post, Bangalore, 560054, India. Phone: 9035044023

E-M ail: parameshradhika@gmail.com

\begin{tabular}{|c|l|}
\hline \multicolumn{3}{|c|}{ Access this Article online } \\
\hline \begin{tabular}{c} 
Quick Response code \\
\cline { 2 - 3 }
\end{tabular} & $\begin{array}{l}\text { Web site: International Journal of Anatomy and Research } \\
\text { ISSN 2321-4287 } \\
\text { www.ijmhr.org/ijar.htm }\end{array}$ \\
\cline { 2 - 3 } & \multicolumn{2}{|c|}{$\begin{array}{l}\text { Accepted: 20 Dec 2016 } \\
\text { Dol: 10.16965/ijar.2016.473 }\end{array}$} & $\begin{array}{l}\text { Received: 10 Nov 2016 } \\
\text { Peer Review: 10 Nov 2016 }\end{array}$ & $\begin{array}{l}\text { Published (O): 31 Jan 2017 } \\
\text { Revised: None }\end{array}$ & Published (P): 31 Jan 2017 \\
\hline
\end{tabular}

\section{INTRODUCTION}

Stature or body height is one most important and useful anthropometric parameter that determines the physical identity of an individual. In anthropometric research, prediction of stature occupies relatively a central position. Estimation of stature of an individual from the skeletal remains or from the mutilated or amputated limbs or parts of limbs in the events of the murders, accidents or natural disasters like floods, tsunamis, earthquakes, plane crashes, train crashes, terrorist attacks usually requires the identification of victims which mainly concerns with the forensic identification analysis[1].

The most detailed description of stature estimation from skeletal remains was compiled by Krogman and Iscan[2]. The first serious research on estimation of length of long bones of 50 maleand 50 female corpses was conducted by Rolletin. Pearson estimated the stature from 
long bones by formulating the regression equations. He also found that these formulae are population specific and should not be applied to individuals of different population groups. Later Dupertuis and Hadden estimated stature in cases where the racial roots of the individual are unknown by formulating general equation. Further it was also noted that discrepancies might occur between right and left parts when using these formulae. Trotter and Gleser made a contribution to setting and improving mathematical methods for determining stature [3]. Studies on the estimation of stature from various body parts such as upper and lower extremities including hand and foot dimensions has been reported[2-6].

The ulna is a long bone on the medial side of the forearm. Proximally the ulna has a bony process called the olecranon process which articulates with the humerus. Distally the ulna bears a styloid process. The olecranon is subcutaneous and easily palpable. The whole length of the subcutaneous border of the ulna is palpable down to the styloid process. The ulna has easily identifiable surface landmarks making the measurements possible even in compromised postures [7]. Therefore, formulae based on the ulna length provide an alternative stature predictor under such circumstances.

Determination of stature of an individual from fragmented remains is still a very demanding assignment despite numerous studies carried out as formula derived in a particular population does not fit worldwide because of genetic, ethnic, dietary and climatic differences. Therefore regression formulae needs to formulated for each specific population. The aim of the study was to find out the relationship between personal stature and length of ulna and to derive linear regression equation to calculate height from length of ulna and vice-versa.

\section{MATERIALS AND METHODS}

The present study was carried out on 300 (150 males and 150 females) healthy medical students in the age group of 18 - 28 years who belonged to Indian population. Inclusion criteria include healthy individuals of Indian origin.Exclusion criteria include students with old fractures, orthopaedic deformity and metabolic or developmental disorders.

In each case, the height and length of right and left ulna were recorded. The measurements were always taken at a fixed time, between 16:00 17:00 pm, to eliminate discrepancies of diurnal variation. The ulna length was defined as the direct distance between the tip of the olecranon process and the styloid process while the elbow in full flexion. Ulna lengths were taken independently on left and right sides of each individual using a digital sliding caliper. The height of the individual was measured between vertex and the floor, when the person is standing erect, in anatomical position and the head in the Frankfort plane, using a standing height measuring instrument.

Data was analyzed using SPSS version 17. Data was summarized using descriptive statistics such as M ean, SD, and Range. Independent sample t-test was used to compare mean differences in height and length of ulna in males and females. Pearson's correlation was used to find the strength of linear relationship between stature and length of ulna. P value $\varangle .05$ was considered as statistically significant.

\section{RESULTS}

The statistical analysis was carried out the mean, standard deviation and range was tabulated in Table 1 . The mean length of right and left ulna in males was $27.52 \mathrm{cms}(\mathrm{SD} \pm 1.63)$ and 27.62 $\mathrm{cms}(\mathrm{SD} \pm 1.69)$ respectively. The mean length of right and left ulna in females was $26.22 \mathrm{cms}$ (SD \pm 1.61$)$ and $26.03 \mathrm{cms}(\mathrm{SD} \pm 1.61$ ) respectively. The difference between mean length of right and left ulna of study group is statistically significant in male, female and both together is shown in table 2. Pearson's correlation coefficient was used determine the relation between length of ulna and height which is represented in table 3 and graph land 2. Correlation coefficient between total height and length of ulna was found to be statistically significant and positive in both males and females which suggests if length of ulna increases or decreases, the height of the subject also increase or decrease vice versa. The linearregression equation for estimation of height from right and left ulna was calculated 
as Stature $=83.224+3.04 \times$ length of right ulna and Stature $=81.06+3.14 \times$ length of left ulna respectively.

Table 1: M ean, SD and Range for all parameters.

\begin{tabular}{|c|c|c|c|c|}
\hline & $\begin{array}{c}\text { Parameter } \\
\text { (cms) }\end{array}$ & $\begin{array}{c}\text { Mean } \\
\text { (cms) }\end{array}$ & SD & Range \\
\hline \multirow{3}{*}{$\begin{array}{c}\text { Both the } \\
\text { sexes } \\
\text { together }\end{array}$} & Height & 164.7 & 7.96 & $140-190$ \\
\cline { 2 - 5 } & $\begin{array}{c}\text { Length of } \\
\text { ulna(right) }\end{array}$ & 26.82 & 1.74 & $20-30$ \\
\cline { 2 - 5 } & $\begin{array}{c}\text { Length of } \\
\text { ulna(left) }\end{array}$ & 26.76 & 1.82 & $20-30$ \\
\hline \multirow{5}{*}{ Males } & Height & 169.46 & 6.53 & $150-184$ \\
\cline { 2 - 5 } & $\begin{array}{c}\text { Length of } \\
\text { ulna(right) }\end{array}$ & 27.52 & 1.63 & $20-30$ \\
\cline { 2 - 5 } & $\begin{array}{c}\text { Length of } \\
\text { ulna(left) }\end{array}$ & 27.62 & 1.69 & $20-30$ \\
\hline \multirow{4}{*}{ Females } & Height & 164.07 & 7.9 & $140-180$ \\
\cline { 2 - 5 } & $\begin{array}{c}\text { Length of } \\
\text { ulna(right) }\end{array}$ & 26.22 & 1.61 & $20-30$ \\
\cline { 2 - 5 } & $\begin{array}{c}\text { Length of } \\
\text { ulna(left) }\end{array}$ & 26.03 & 1.61 & $20-30$ \\
\hline
\end{tabular}

Table 2: Comparison of length of right and left ulna.

\begin{tabular}{|c|c|c|c|}
\hline Subjects & $\begin{array}{c}\text { Length of Right ulna } \\
\text { Mean } \pm \text { SD } \\
\text { (Range) }\end{array}$ & $\begin{array}{c}\text { Length of left ulna } \\
\text { Mean } \pm \text { SD } \\
\text { (Range) }\end{array}$ & P value \\
\hline $\begin{array}{c}\text { Both sexes } \\
\text { together }\end{array}$ & $\begin{array}{c}26.82 \pm 1.74 \\
(20-30)\end{array}$ & $\begin{array}{c}26.76 \pm 1.82 \\
(20-30)\end{array}$ & $P \varangle 0.01^{*}$ \\
\hline Males & $\begin{array}{c}27.52 \pm 1.63 \\
(20-30)\end{array}$ & $\begin{array}{c}27.62 \pm 1.69 \\
(20-30)\end{array}$ & $P \varangle 0.01^{*}$ \\
\hline Females & $\begin{array}{c}26.22 \pm 1.61 \\
(20-30)\end{array}$ & $\begin{array}{c}26.30 \pm 1.61 \\
(20-30)\end{array}$ & $P \varangle 0.01^{*}$ \\
\hline
\end{tabular}

\section{*Pvalue is statistically significant}

Table 3: Correlation coefficient.

\begin{tabular}{|c|c|c|c|}
\hline Subjects & $\begin{array}{c}\text { Correlation } \\
\text { coefficient [r] } \\
\text { (Right ulna) }\end{array}$ & $\begin{array}{c}\text { Correlation } \\
\text { coefficient [r] } \\
\text { (left ulna) }\end{array}$ & P-value \\
\hline Both sexes together & 0.44 & 0.51 & $\mathrm{P}<0.01^{*}$ \\
\hline Males & 0.45 & 0.51 & $\mathrm{P} \varangle 0.01^{*}$ \\
\hline Females & 0.27 & 0.32 & $\mathrm{P}<0.01^{*}$ \\
\hline
\end{tabular}

$*$ Pvalue is statistically significant

Graph 1: Scatter plot showing the Correlation between the Height and length of Left Ulna.

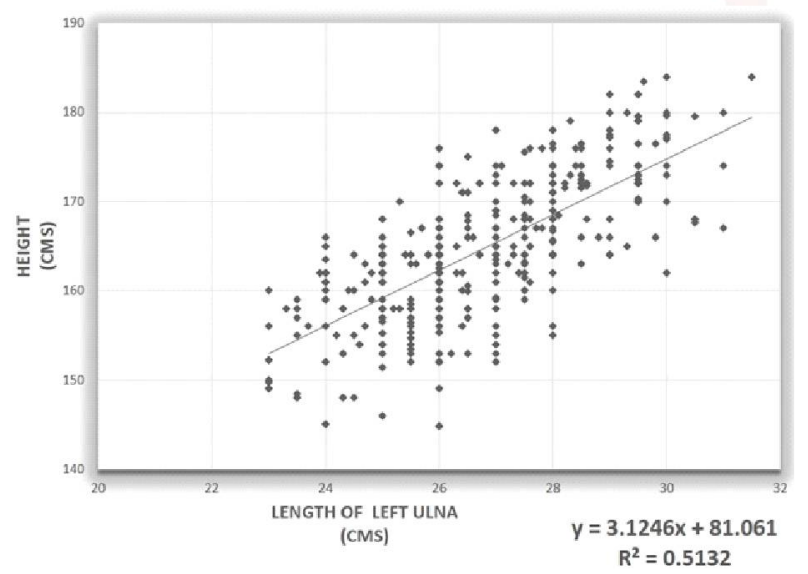

Graph 2: Scatter plot showing the Correlation between the Height and length of Right UIna.

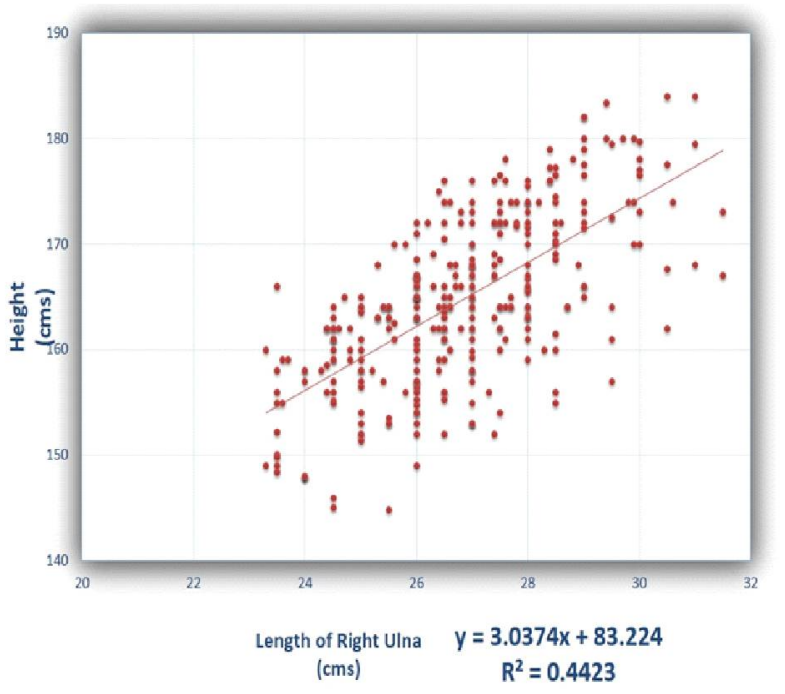

DISCUSSION

Sex determination of an unknown individual and the estimation of stature is one of the most important aspects in forensic sciences and anthropological studies. Estimation of stature is essential for the calculation of body mass index, which is used for assessment of nutrition. However, its measurement is not always practical in old or frail bedridden patients who cannot stand or those who are suffering from vertebral column deformities. In such patients, formulae based on the ulna length provide an alternative stature predictor [8]. Pan worked on cadavers and derived relation between total ulnar length and total height of an individual [9]. According to Trotter $M$ et al., there is an increase in the height of $2.5 \mathrm{~cm}$ after death [10]. Hence prediction of height using ulna in living has definitive advantage over the cadavers.

Various authors have observed that there is secular change and allometry between sexes among population. As the rate of skeletal maturity in males and females tend to vary during the course of development, gender specific formulae is required for the estimation of height [11]. In the present study, there was no statistical difference between the length of ulna between males and females. The Correlation coefficient between the total height and ulna length was found to positive indicating a strong relationship between the two parameters. The positive correlation suggests if length of ulna increases or decreases, the height of the subject also increases or decreases and vice versa. 
In the present study the regression formulae for estimation of stature by both right and left ulna was derived and compared with the previous studies in the table given below. When compared with other studies it can be concluded that each population has a different regression formulae for calculating the stature.

Table 4: A comparison of linear regression equation of the present study with previous studies.

\begin{tabular}{|c|c|c|c|}
\hline Authors & Place \& year & Subjects & Linear regression equation \\
\hline Allbrook [12] & Africa 1961 & Males & $\begin{array}{c}\text { Stature }=88.94+3.06 \text { xulna } \\
\text { length } \pm 4.4 \\
\text { (Standard error) }\end{array}$ \\
\hline Athwale [13] & Maharashtra 1963 & Males & $\begin{array}{c}\text { Stature }=56.97+3.96 \mathrm{x} \\
\text { average length of right and } \\
\text { left ulna } \pm 3.64\end{array}$ \\
\hline Maloy [5] & West Bengal 2009 & Males & $\begin{array}{c}\text { Stature }=50.642+4.1896 \mathrm{x} \text { right } \\
\text { ulna } \pm 7.7302 . \\
\text { Stature }=76.289+3.256 \times \text { left } \\
\text { ulna } \pm 9.0826 .\end{array}$ \\
\hline \multirow{2}{*}{ Thummer [14] } & \multirow{2}{*}{ Gujarat 2011} & Males & $\begin{array}{c}\text { Stature }=81.11+3.12 \mathrm{x} \\
\text { length of right ulna. Stature } \\
=65.76+3.67 \mathrm{x} \text { length of left } \\
\text { ulna }\end{array}$ \\
\hline & & Females & $\begin{array}{l}\text { Stature }=17.10+5.34 \times \text { length } \\
\text { of right ulna. Stature } \\
=18.95+5.33 \times \text { length of left } \\
\text { ulna }\end{array}$ \\
\hline \multirow{2}{*}{ Anjali P. [15] } & \multirow{2}{*}{ Marathwad 2012} & Males & $\begin{array}{c}\text { Stature }=93.45+2.92 x \\
\text { length of ulna }\end{array}$ \\
\hline & & Females & $\begin{array}{c}\text { Stature }=113.89+2.37 \mathrm{X} \\
\text { length of ulna }\end{array}$ \\
\hline Present Study & Karnataka & $\begin{array}{l}\text { Males \& } \\
\text { Females }\end{array}$ & $\begin{array}{l}\text { Stature }=83.224+3.04 x \\
\text { length of right ulna } \\
\text { Stature }=81.06+3.14 x \\
\text { length of left ulna }\end{array}$ \\
\hline
\end{tabular}

\section{CONCLUSION}

In the present study an attempt was made to documents a relationship between the ulna and height in Indian population. There was statistical difference between right and left ulna. A positive correlation was found between stature and length of ulna. Simple linear regression equation derived can be used for estimation of height from ulna and vice versa. Thus the data of this study will be of practical use in Medico legal investigations and in anthropometry. Hence the present study would be useful for Forensic M edicine experts and Anthropologist.

\section{Conflicts of Interests: None}

\section{REFERENCES}

[1]. Jasuja O.P, Singh G. Estimation of stature from Hand and Phalange length. Journal of Indian Academy of Forensic Medicine 2004;26(3): 100-106
[2]. W.M. Krogman, M .Y. lÿs, can, The Human Skeleton in Forensic Medicine, Charles C. Thomas, Springfield, IL, 1986.

[3]. O. Celbis, H. Agritmis Estimation of stature and determination of sex from radial and ulnar bone lengths in a Turkish corpse sample. Forensic Science International 2006; 158:135-139.

[4]. M eenakshi P. Borkar. Estimation of height from the length of humerus in western region of $M$ aharashtra. Int J Res M ed Sci. 2014; 2(2): 498-500.

[5]. M ondal M, Jana TK, Das J, Biswas S. Use of the length of the ulna in the estimation of stature in living adult males in the Burdwan district and in the adjacent areas of West Bengal. J Anat Soc Ind. 2009;58(1):16-19.

[6]. Khanapurkar S, Radke A. Estimation of stature from hand length, foot length and head length in $M$ aharashtra region. Indian Journal of Basic $\& A p-$ plied Medical Research. 2012;1(2):77-85

[7]. L Ebite, T Ozoko, A Eweka, P Otuaga, A Oni, F Om'Iniabohs. Height: Ulna Ratio: A M ethod of Stature Estimation In A Rural Community in Edo State, Nigeria. The Internet Journal of Forensic Science. 2007;3:1-4.

[8]. Ilayperuma I, Nanayakkara, G, Palahepitiya N. A model for the estimation of personal stature from the length offorearm. Int. J. Morphol.2010; 28(4):1081-1086.

[9]. Pan N. Estimation of the height from different long bones in Bengalis. J Anat. Soc. Ind. 1924;58:3.74.

[10]. Trotter M and Gleser GC. Estimation of stature from long bones of American whites and Negros.Am.J.Phys.Anthropol1952;10:463-514.

[11]. M eadows, L. \& Jantz, R. L. Secular changes in long bone length and proportion in the United States 1800-1970. Am. J. Phys. Anthropol. 1999;110:5767.

[12]. Albrook D. The estimation of stature in British and East African males based on tibial and ulnar bone lengths, Journal of Forensic M edicine 1961;(8) 1527.

[13]. Athwale M C. Anthropological study of height from length of forearm bones. A study of one hundred $M$ aharashtrian make adults of ages between 25-30 years. American Journal of Physical Anthropology. 1963;21:105-12.

[14]. Thummar B, Patel Z, Patel S, Rathod SP. M easurement of Ulnar Length for estimation of Stature in Gujarat. NJIRM 2011;2(2):36-40.

[15]. Anjali Prasad, V B Bhagwat, Satish Porwal, D S J oshi. Estimation of Human Stature from length of ulna in M arathwada Region of M aharashtra Int J Biol Med Res. 2012;3(4):2337-234.

How to cite this article: Ashish Pandey, Radhika P.M, Shailaja Shetty. ESTIM ATION OF HUM AN STATURE FROM LENGTH OF ULNA IN INDIAN POPULATION. Int J Anat Res 2017;5(1):3350-3353. DOI: 10.16965/ ijar.2016.473 